\title{
A DIMENSÃO CONSTITUCIONAL DO ESTADO SOCIAL DE DIREITO NA ESPANHA*
}

\author{
FRANCISCO BALAGUER CALLEJÓN***
}

\begin{abstract}
RESUMO: Trata-se o presente texto de uma análise do Estado Social, e mormente de sua configuração na Espanha, a partir dos aspectos axiológicos, sociais e políticos, articulada em torno do ponto de referência da Constituição. Privilegia-se o exame do choque entre a ideologia do determinismo econômico e o Estado Social, bem como a verificação das formas e perfis deste.

PALAVRAS-CHAVE: Estado Social. Constituição. Economia.
\end{abstract}

\begin{abstract}
The text presented here is an analysis of the Social State, and mainly of its configuration in Spain, from the point of view of the axiological, social and political aspects, articulated around the Constitution's reference point. The article devotes itself to examining the shock between the economical determinism ideology and the Social State, as well as to verifying its formats and profiles.

KEYWORDS: Social State. Constitution. Economy.
\end{abstract}

SUMÁRIO: 1. Introdução; 2. Estado social e constituição normativa; 3. O político e o econômico no Estado social; 4. Construção e "desconstrução" do Estado social; 5. Os perfis constitucionais do Estado social; 6. Conclusões; 7. Bibliografia.

SUMMARY: 1. Introduction; 2. Social State and normative Constitution; 3. The political and the economical in the Social State; 4. Social States' Construction and "deconstruction"; 5. The constitutional profiles of the Social State; 6. Conclusions; 7. Bibliography.

\section{INTRODUÇÃO}

No Estado social como princípio convergem referentes econômicos, jurídicos, sociais e políticos que devem ser levados em conta. Isto não pode nos conduzir, a meu juízo, a uma perspectiva pluridisciplinar (assim, GARCÍA COTARELO, 1986, p. 16) que mantenha distintos níveis de análise desenvolvidos separadamente pelo pesquisador. Pelo contrário, aqui se efetuará uma abordagem constitucional do Estado social de Direito, com as ferramentas próprias da perspectiva jurídica requeridas por esta formulação estatal, que não são outras que as da Constituição normativa do Estado Constitucional de Direito (cfr. BALAGUER, F., 1997). Portanto, serão levados em conta os aspectos axiológicos, sociais e políticos (também econômicos) de modo a

\footnotetext{
* Traduzido por Hugo César Araújo de Gusmão.

** Catedrático de Direito Constitucional da Universidade de Granada e Catedrático Jean Monnet de Direito Constitucional Europeu.
} 
integrá-los no discurso jurídico-constitucional. A Constituição, entretanto, não é um elemento a mais deste discurso, senão o ponto de referência em torno do qual o próprio discurso pretende se articular.

Com esta advertência prévia tentamos inicialmente desobstruir o caminho no que concerne à pluralidade de enfoques metodológicos sob os quais o Estado social já foi abordado na doutrina. Não serão omitidas, portanto, as realidades política, social ou econômica, porém tampouco se partirá de um condicionamento absoluto da estrutura constitucional por algum desses fatores que converta a Constituição numa "folha de papel” na famosa expressão que todos conhecemos (LASSALE, F., 1862, p. 119). Isto é, não se aceita, de partida, uma abordagem estritamente "economicista" em razão da qual o desenvolvimento e a efetividade do Estado social como princípio constitucional dependam exclusivamente da última revolução tecnológica que tenha sido produzida no Japão ou nos Estados Unidos, ou das necessidades de acumulação do capital, por exemplo.

Em estreita relação com o anterior, deve-se levar em conta a forte impregnação ideológica evidenciada nos estudos sobre o Estado social. Certamente em relação com as primeiras linhas de defesa ante a implantação do Estado social, que foram essencialmente jurídicas e baseadas numa presumida incompatibilidade entre Estado social e Estado de Direito. A ciência jurídica constituiu, no entanto, um freio muito limitado à pressão política que deu origem ao grande pacto que na Europa consagrou a fórmula do Estado social. Para a desarticulação do Estado social, buscou-se uma metodologia mais eficaz: a ciência econômica, que recupera os termos deterministas do racionalismo universalista expondo como verdades absolutas e inevitáveis os postulados do modelo econômico vigente e inclusive de uma determinada política econômica (cabe reconhecer, entretanto, que as tendências “economicistas” não foram, historicamente, patrimônio de uma determinada corrente de pensamento: também o marxismo conseguiu se impor frente a outros movimentos socialistas baseado numa formulação teórica solidamente assentada na análise econômica, a partir da qual oferecia confiança na inevitabilidade da transformação do sistema). Como indica P. DE VEGA, pretende-se impor agora a razão econômica ante a razão política democrática (DE VEGA GARCÍA, P., 1997, p. 719). De tal maneira que "no processo de mundialização dos mercados tudo se transforma em mercadoria (inclusive o próprio Estado e os compromissos políticos)”, de modo que a essência mesma da mundialização choca frontalmente com a essência do Estado e da política (DE VEGA GARCÍA, P., 1998, p. 18).

A tensão ideológica ante o Estado social pode suscitar algumas situações paradoxais se contempladas desde o devir histórico. Argumentos semelhantes aos que se opuseram num determinado momento frente à implantação do Estado social (a segurança jurídica) poderiam hoje se opor à sua "desconstrução”. Como indica GOMES CANOTILHO, "não há razão para que os princípios do Estado de direito não valham como princípios contra eventuais irracionalidades legislativas”, como pode ocorrer se as soluções legislativas representam uma desproporcionada e retroativa perturbação de direitos subjetivos, por exemplo em matérias de seguridade social e de pensões (GOMES CANOTILHO, J.J., 1998, p. 47). Porém, tanto antes como hoje 
em dia, os argumentos jurídicos dificilmente servirão para brecar o desenvolvimento da política. Não se pode pedir à Constituição mais do que esta pode dar, nem para promover nem para limitar o Estado social.

A impregnação ideológica se manifesta também em relação às linhas de defesa do Estado social, nas quais se aprecia as vezes um certo sentimento de perda não suficientemente contrastado com a realidade do devir histórico. A idéia tão comum de que "o Estado social já não é o que era”, poderia certamente se reformular, de maneira mais realista: o Estado social nunca foi o que era”, nunca foi (ao menos na Espanha) o que pensamos que era, projetando para o futuro avanços que ainda não se haviam concretizado. Por outra parte, não se pode ocultar que o Estado social, enquanto expressão de um pacto entre diversos agentes sociais não é uma fórmula homogênea, razão pela qual, à semelhança do que ocorre com a Constituição (embora em menor medida) não existe uma imagem comum do Estado social, senão distintas concepções. Estas concepções oscilam entre a garantia de uma mínima procura existencial orientada basicamente para evitar conflitos sociais excessivamente graves que possam por em perigo o sistema (o que, mais que um conceito de Estado social é uma deformação deste princípio constitucional) até propostas de transformação radical do modelo econômico. Estas últimas tendências se manifestam também na Constituição e são, portanto, uma opção constitucional válida. Como indica J. JIMÉNEZ CAMPO, esta “tensão entre ser e dever ser não significa, claro está, má-formação alguma no Direito constitucional nem revela, tampouco, mais contradições que as que a própria sociedade mostra”, se bem, adverte este autor que, embora a Constituição legitime a transformação do ordenamento, "uma sociedade nunca se propõe mais tarefas do que as que pode consumar” (JIMÉNEZ CAMPO, J., 1984, p. 281). A este respeito, não podemos deixar de ressaltar, parafraseando aqui o mote de uma velha polêmica marxista, a dificuldade (para não falar de impossibilidade: cfr. C. DE CABO, 1986, pp. 117 y ss.) de estabelecer o "Estado social num só país”, a partir desta perspectiva de transformação radical do modelo capitalista, nestes tempos de globalização e de interdependência econômica.

Em todo caso, parece claro que, naquilo que o Estado social tem de procura existencial, sua fundamentação nem sempre foi compatível com a pretensão isonômica que pulsa sob uma formulação minimamente profunda deste princípio. Nem as opções contributivas do sistema de previsão social nem as assistenciais que vieram a completá-lo estão necessariamente baseadas nesta pretensão isonômica. Naquilo que o Estado social tem de proposta de transformação social, seus contornos e seus limites são necessariamente imprecisos. Sua crise é a de um projeto alternativo que não chegou a se realizar. No entanto, entre a mera atividade assistencial do Estado e a transformação social qualitativa há zonas de intervenção do Estado e de igualação social. A reivindicação destas políticas e sua ativação formam parte também do significado histórico do Estado social como princípio nuclear de uma cultura constitucional de progresso, não só na promoção da igualdade como também da dignidade da pessoa.

Partindo desta perspectiva, não podemos esquecer que o princípio do Estado social é expressão de um pacto histórico. Este pacto é o mesmo que está na origem da Constituição normativa na Europa e implicou o reconhecimento do pluralismo social 
e político e a aceitação de que não se podia impor uma única ideologia ou um único interesse político na ação do Estado e dos poderes públicos. O princípio do Estado social é congenial com uma nova concepção do princípio democrático que acaba por superar o mito da vontade uniforme do povo como coletividade homogênea, engendrado pelo constitucionalismo oligárquico para defender os interesses espúrios de um determinado grupo social. A vontade popular se expressa no processo constituinte, no nosso caso mediante a incorporação do princípio do Estado social e de suas múltiplas manifestações no texto constitucional. A partir daí, é a tensão inerente ao princípio democrático no nível legislativo (enquanto vontade da maioria) o que deverá orientar o modo e o ritmo de realização deste princípio.

Em todo caso, a interação entre Estado social e princípio democrático é expressiva tão só de uma parte das questões que surgem em torno à formulação constitucional do Estado social, enquanto Estado social e democrático de Direito. Cabe partir desta formulação mais ampla para compreender, com certa perspectiva histórica, o sentido constitucional do Estado social.

\section{ESTADO SOCIAL E CONSTITUIÇÃO NORMATIVA}

\subsection{O constitucionalismo do Estado social e democrático de Direito}

A fórmula do Estado social de Direito que o artigo 1.1 CE acolhe ("Espanha se constitui num Estado social e democrático de Direito...”) foi forjada na Alemanha por H. Heller no período entre-guerras (HELLER, H., 1929). HELLER partia da constatação do temor da burguesia ante a transformação do Estado liberal de Direito em Estado social de Direito, como consequência do acesso das massas ao poder legislativo. Este temor situava os termos do debate político na alternativa entre a aceitação do Estado social de Direito ou a ditadura. A "democracia social" deveria significar "a extensão da idéia do Estado material de Direito à ordem do trabalho e das mercadorias” (p. 290), a prevalência do Estado de Direito sobre a economia (p. 299), já que "a submissão da economia às leis sob o Estado de Direito não é outra coisa que o jugo dos meios por parte dos fins da vida” (p. 301). Frente a esta alternativa se observa a tendência a opor a Ditadura enquanto "violência torpemente emascarada pela ideologia" (p. 299), pois "a burguesia começa já a perder a esperança no ideal do Estado de Direito e a renegar seu próprio universo cultural” (p. 287).

A fórmula foi incorporada, após o final da segunda guerra mundial e a derrota das ditaduras fascistas, à Lei Fundamental de Bonn, e sintetiza muito bem a evolução do constitucionalismo que conduz às atuais constituições normativas.

Efetivamente, se consideramos o triplo processo de democratização, socialização e normativização do Direito constitucional (POSADA, 1934, pp. 32, 59-61) podemos comprovar como cada um destes processos converge para a tríade integrada pela fórmula constitucional espanhola. A democratização a que se abre o direito constitucional a finais do século XIX sugere a incorporação ao processo político de novos grupos sociais, até esse momento marginalizados, que promovem uma progressiva intervenção do Estado na sociedade. As reivindicações sociais que estes grupos levam ao Estado dá lugar ao surgimento de um novo Direito constitucional já durante o período entreguerras no qual junto aos direitos de resistência tradicionais no constitucionalismo 
aparecem os direitos laborais e sociais. Começa-se a exigir portanto, uma atividade distinta do Estado, de tal modo que agora já não se trata de que o Estrado se retraia, que não intervenha, senão, pelo contrário, de promover a contínua intervenção do Estado na vida social, se bem que esta intervenção tem como pressuposto prévio o próprio caráter democrático do Estado, isto é, que seja a sociedade que decida o sentido desta intervenção. Tenta-se acabar com a separação entre a sociedade e Estado e converter o poder político num autêntico representante da sociedade, não tanto controlá-lo (como pretendia o liberalismo: separar os poderes para, mediante seu controle recíproco assegurar a não intervenção estatal e a liberdade política dos cidadãos) quanto submetê-lo à suas pretensões. Como indicava Forsthoff, a luta para participar na formação da vontade do Estado será a luta para participar na redistribuição (FORSTHOFF, E., 1961, p. 57).

A democratização e subseqüente socialização do direito constitucional deveriam ter levado a sua normatização. De fato, as primeiras tentativas neste sentido se produzem durante este período entre-guerras. No entanto, as lutas políticas desta época, que em alguns países se produziam nos limites do próprio Estado liberal-democrático, acabaram por substituir este tipo de Estado por um novo Estado totalitário ou autoritário, revogando assim todo o sistema legal anterior, e acabando com o Estado de Direito e com as Constituições da época. O temor manifestado por HELLER no trabalho retromencionado, que já se baseava na experiência da implantação do fascismo na Itália e das tendências nacionalistas que brotaram nesta época, se fez trágica realidade.

Será necessário esperar o final da segunda guerra mundial para que surja uma nova onda de constituições nas quais se produza um novo impulso do processo de democratização, socialização e normativização que já havia começado no período entre-guerras. Assim culmina o processo de democratização e se toma consciência dos riscos implicados no conceito de democracia que estava presente no primeiro constitucionalismo, baseado na identificação da democracia com a vontade do povo considerada como vontade da maioria. Esta concepção só tinha sentido sob a perspectiva, presente no constitucionalismo garantista, de que o povo é uma coletividade homogênea, com interesses e valores semelhantes, que o povo se identifica com um determinado grupo social, neste caso, a burguesia. Porém não quando, como se fez evidente a partir do desenvolvimento dos movimentos socialistas, a política já não é a vontade de um único grupo social, senão o resultado do conflito entre diversos setores que tentam impor seus pontos de vista e desenvolver seus próprios interesses. A democracia é entendida agora não só sob a perspectiva da preferência devida à maioria senão também a partir do respeito às minorias. Em definitivo, produz-se uma dissociação do conceito de democracia utilizado no primeiro constitucionalismo de tal modo que por cima da vontade democrática exercida dentro do marco constitucional, se situa a democracia constitucional, à qual o legislador, a maioria em definitivo, deve sempre se submeter. Esta democracia constitucional se assenta sobre o consenso fundamental dos diversos setores sociais e a própria Constituição tenta sempre proteger esse consenso limitando a capacidade de decisão da maioria, seja do signo que for. A normatividade da Constituição, a transformação do constitucionalismo em 
autêntico Direito constitucional, serão a garantia deste pacto fundamental, de tal modo que a interrelação entre democratização e normativização resulta assim manifesta.

O consenso fundamental, porém, não há de tratar somente de procedimentos formais de configuração democrática do Estado. Tem também um conteúdo material, expressado sob a fórmula do Estado social de Direito. Acentua-se então o processo de socialização, promovendo uma intervenção cada vez maior do Estado na sociedade, e, portanto, reduzindo a separação entre a sociedade e o Estado. Expressa-se, assim, um claro sentido transformador que não constitui só uma possibilidade aberta aos poderes públicos, senão em muitos preceitos também uma obrigação dos poderes públicos. O Estado constitucional passa a ser um Estado de Direito que não só é democrático como também social, isto é, um Estado que fomenta uma maior igualdade social e que deve garantir não só a liberdade dos cidadãos, como também as condições materiais que tornem possíveis a liberdade e a dignidade.

Porém, as condições do pacto que dá lugar a este conteúdo material, ao Estado social, em definitivo, não foram igualitárias. Daí que como indica A. LÓPEZ, a transformação do Estado liberal em Estado Social, tenha sido uma transformação débil: "débil por que o Estado Social se formula a partir do Estado Liberal e com aceitação de muitos dos seus postulados. Esta não foi a transformação protagonizada pela burguesia em relação às formas políticas do Antigo Regime: abatendo-as a radice. O Estado liberal nasce, pois, de uma transformação forte. De uma transformação revolucionária, para chamar as coisas pelos seus nomes. Por outro lado, o Estado Social é antes fruto do temor de uns à revolução e do temor de outros à ditadura, temores que tentaram conjurar com o encontro de um ponto de consenso de reformismo de compromisso, reformismo defensivo para uns, único reformismo possível para outros.” LÓPEZ y LÓPEZ, A.M, 1996, p. 430).

Certamente estas reflexões são corretas: o Estado liberal surge de um processo revolucionário no qual os vencedores impõem suas condições, enquanto o Estado social surge de um pacto no qual os outrora vencedores mantém uma posição de vantagem. Não obstante, esta debilidade política inicial do Estado social, não subtrai seu protagonismo, a meu juízo, na conformação da fórmula "Estado social e democrático de Direito", como expressão deste triplo processo de democratização socialização e normativização antes enunciado. Se a normatividade constitucional está estreitamente relacionada com o pacto social contido na Constituição, fica evidente que uma alteração deste pacto pode suscitar também uma frustração do componente normativo e democrático do Estado. Daí ser possível afirmar com C. DE CABO que a crise do Estado social implica a do Estado democrático e a do Estado de direito e que sua superação pode provocar também a transformação destes últimos (DE CABO, C., 1986, pp. 10, 57; 1993, p. 28).

Evidencia-se assim a profunda imbricação dos termos da fórmula constitucional, enquanto unidade (GARRORENA, A., 1984, p. 203), da qual se pode dizer de acordo com GARCÍA PELAYO, que não é uma simples agregação ou justaposição de componentes, senão a articulação destes numa totalidade conceitual”, de tal maneira que todos se relacionam entre si mediante uma conexão de interdependência significativa" e que, enquanto totalidade, vai mais além de cada um dos seus componentes, tendo 
a capacidade para gerar algo novo. Deste modo, a fórmula se configura como “a essência ou substância da Constituição espanhola à qual o resto de preceitos constitucionais dá existência normativa, por isso tais normas têm um caráter cunhador, gerador, germinal ou troncal de outras normas da Constituição “ (GARCÍA PELAYO, 1984, pp. 93, 96, 104).

2.2 O Estado social e democrático de Direito como princípio constitucional

A partir da evolução histórica que conduz ao Estado social e democrático de Direito, se compreende a transcendência que este princípio tem no ordenamento constitucional. Trata-se de um princípio nuclear (COSSÌO DÍAZ, J.R., 1989, p. 153 e ss.) que expressa o próprio sentido da Constituição normativa através das distintas vertentes incorporadas à fórmula constitucional do Estado social, democrático e de Direito. Partindo desta trajetória pode-se entender como o Estado constitucional de Direito se conformou na Europa como um Estado social de Direito, de tal maneira que o trânsito do Estado legal de Direito ao Estado constitucional de Direito é também o do Estado liberal ao Estado social.

A partir desta perspectiva, a fórmula expressa uma coerência conceitual superadora de anteriores conflitos: o Estado constitucional de Direito é, em virtude do consenso social sobre o qual se assentam as constituições normativas, um Estado social e um Estado democrático (no sentido de uma democracia representativa e pluralista, questão distinta se estabelece se se pensa numa democratização social e econômica de maior alcance: cfr. DÍAZ, E., 1966). Sem estas duas conotações não seria possível falar de Estado de Direito no Estado constitucional das Constituições normativas: o reconhecimento do pluralismo social, da diversidade de interesses que dá lugar a um autêntico Direito constitucional se manifesta numas regras constitucionais que respondem à síntese consentida entre os grupos que propugnam a transformação social e os que defendem a limitação da atividade estatal. Esta síntese se manifesta nas regras constitucionais dedicadas ao Estado social e é expressiva, em si mesma, de uma concepção de democracia assentada sobre o consenso e a integração.

Não há pois, na atualidade, contradição essencial entre os termos que caracterizam o Estado como democrático, social e de Direito. Isto não quer dizer que o ordenamento jurídico não tenha que resolver contradições para responder às exigências derivadas da integração destes termos. Como indica J. JIMÉNEZ CAMPO, “o intérprete parece obrigado a fazer da história um sistema, a coordenar significados que, muitas vezes nasceram polemicamente e que ainda hoje acusam, no seu difícil ajuste, as tensões próprias de uma sociedade dividida, que assim se reconhece no seu ordenamento." (JIMÉNEZ CAMPO, J., 1984, p. 274). A maior intervenção dos poderes públicos sobre a sociedade, a progressiva interrelação sociedade-Estado, gera necessariamente tensões que devem e podem ser resolvidas através das técnicas criadas pelo Estado de Direito. A este respeito, o equilíbrio é promovido pela própria condição integradora da fórmula, ao fazer com que seus elementos integrantes atuem como "condição corretora” (GARRORENA, A., 1984, p. 211) da primazia excessiva de qualquer destes.

Por outra parte, a fórmula constitucional incorpora um componente dinâmico especialmente intenso no que tange à vertente social: a criação das condições que tornem possível a dignidade real dos cidadãos e o usufruto dos direitos nunca será 
um fim constitucionalmente alcançado. A suavização de algumas das tensões derivadas da desigualdade deve ser contrastada com a aparição de novos conflitos que demandam uma reativação do artigo 9.2 CE e do princípio da igualdade substancial.

Além do sentido unitário contido na fórmula, cada um dos seus elementos se reflete nos artigos da Constituição em múltiplos preceitos constitucionais. Mais adiante nos deteremos naqueles especificamente voltados para o Estado social. Por sobre esta diferenciação, cabe ressaltar, no entanto, sua vertente integradora, já que muitos dos aspectos referidos usualmente como expressão de algum dos elementos da fórmula estão estreitamente relacionados com os demais. Enquanto ordenação tendencialmente sistemática seus elementos se ajustam entre si adquirindo novas funções e novos significados.

\section{O POLÍTICO E O ECONÔMICO NO ESTADO SOCIAL}

\subsection{Determinismo econômico e redução do espaço político}

No desenvolvimento do Estado social convergem, como não poderia ser de outro modo, diversos fatores sociais, econômicos e políticos. O distinto peso que estes fatores tenha tido na evolução histórica desta fórmula estatal é de difícil avaliação. As teorias econômicas de Keynes, a evolução do capitalismo, os movimentos sociais que lutaram por sua superação, a existência de uma alternativa global desde 1917 até a queda do muro de Berlim são, entre outros, aspectos que devem ser considerados para compreender a transformação do Estado liberal em Estado social.

No entanto, na crise do Estado social, a interpretação econômica é a que logrou se impor de maneira opressiva sobre qualquer outra consideração. Inclusive fatores que aparentemente poderiam ser suscetíveis de uma valoração política, como a queda dos regimes do Leste Europeu, encontram-se integrados na explicação econômica, como uma prova a mais da impossibilidade de existência de alternativas ao capitalismo ou de uma determinada política econômica. Porém esta argumentação "economicista" manifesta uma clara debilidade quando se apresenta como auto-suficiente: que o sistema capitalista seja aquele que torne possível um maior desenvolvimento econômico, é algo que pode ser aceito sem maior debate. Que o desenvolvimento econômico seja um fim em si mesmo ao qual tudo tenha que estar sujeito é algo que não pode ser aceito.

Todavia, este ponto de partida surge como um axioma ao qual devem se acomodar necessariamente as atitudes sociais e políticas. A importância das abordagens "economicistas" se acrescenta devido ao processo de globalização que faz com que o desenvolvimento econômico dependa de instâncias externas ao Estado e portanto, do âmbito da política e dos condicionantes constitucionais. Porém, como indica P. DE VEGA, esta perda de espaços no contexto do Estado não foi produzida por uma incompatibilidade física e puramente mecânica entre uma realidade econômica mundial e uma realidade política geograficamente limitadas, senão por uma incompatibilidade entre os critérios definidores e que dão sentido à vida econômica (a lógica do cálculo e do lucro) e os que definem a organização política e estatal (a lógica política e valorativa)” (DE VEGA, P., 1998, p. 18).

Do ponto de vista constitucional, a imposição da lógica do cálculo é extremamente perigosa por que pode obrigar a uma reconsideração das exigências constitucionais 
em matéria econômica e a vulnerações da ordem constitucional. De fato, a aceitação incondicionada da lógica econômica já supõe uma ruptura do pacto constituinte que deu lugar ao Estado social. Como indica A. Cantaro, "é verdade que o estado social não postulava a superação sempre e a tout court do cálculo econômico. No entanto, não resta dúvida que com sua afirmação se realiza um compromisso político e social que legitima, em certas condições, a criação, por parte dos poderes públicos, de um governo político de mercado, a correção - e inclusive as vezes a suspensão - do cálculo econômico em nome de outra racionalidade” (CANTARO, A., 1997, p. 174).

As limitações à capacidade de decisão política interna não são só limitações ao Estado social senão também limitações ao Estado democrático. O poder econômico se desvincula assim em grande medida dos entraves impostos pelo poder político e começa a funcionar em grande parte como um poder autônomo não submetido a controle democrático. A lógica do mercado se impõe a qualquer outra consideração. De fato, a lógica econômica não só domina a democrática como acaba por impregná-la, reduzindo-a a um procedimento “economicista” (DOGLIANI, M., 1997, p. 690). A transformação experimentada nos últimos anos é notável, pois passamos da tentativa de democratizar a economia (cfr. ABENDROTH, W. 1965, pp. 40 e ss.) à realidade de uma "economização" da democracia.

Como recordava GARCÍA PELAYO, o Estado social tem uma pretensão mais ampla que a de uma mera função estatal e isto permite diferenciá-lo de outros conceitos próximos como o Estado de bem-estar, o Estado assistencial, o Estado providência, etc, pois se trata de "uma configuração global do Estado" que exige uma conformação democrática (GARCÍA PELAYO, M. 1975, pp. 48-9). No entanto, os riscos para o princípio democrático podem proceder não somente de um modelo autoritário clássico, como também da “ditadura dos mercados financeiros” que hodiernamente ameaçam não já o Estado social senão o Estado mesmo configurando um poder privado de escala planetária (LÓPEZ y LÓPEZ, A. M., 1996, p. 461).

\subsection{Uma teoria constitucional e européia do mercado}

Ante a expansão do "economicismo", torna-se cada vez mais necessária uma teoria constitucional do mercado (HÄBERLE, P., 1997, pp. 17, 29), da qual se podem destacar alguns elementos essenciais: antes de tudo, a "natureza instrumental" do mercado e a inaplicabilidade do modelo do mercado a determinados âmbitos culturais e setores sociais; igualmente, a possibilidade de aplicar ao mercado princípios constitucionais de controle do poder (HÄBERLE, P., 1997, pp.. 19, 24, 29). Na medida em que esta teoria constitucional se estenda a âmbitos geográficos cada vez mais extensos, haverá possibilidades de resistir ao efeito deste "economicismo" que pretende reduzir ao mínimo a política e as exigências constitucionais. A este respeito, não cabe dúvida de que o processo de integração européia é simultaneamente um risco e uma oportunidade para lutar contra as pretensões de determinação econômica dos espaços políticos e sociais. Se a União Européia mantiver seus déficits políticos e constitucionais, o risco predominará sobre a oportunidade que se pode abrir uma vez que exista um autêntico espaço público e constitucional europeu no qual seja possível uma plena realização do princípio democrático. 
A integração européia pode significar assim uma resposta a favor do espaço político e constitucional e contra o "economicismo", enquanto permita expandir estes espaços a um âmbito supra-nacional no qual se possa resistir à incidência econômica da globalização. Partindo desta perspectiva, poder-se-ia neutralizar também o efeito da progressiva extensão da periferia (destacado por C. de CABO, 1986, cfr. pp. 124 e ss.) e da conseguinte desigualdade gerada por esta entre os Estados europeus. É necessário, no entanto, que a integração européia não fique reduzida a um mercado. O mercado não pode prover-se a si mesmo e não pode prover-se com uma mínima regulação: requer um espaço social, político, cultural e, em definitivo constitucional. A Europa não pode ser somente um mercado, nem pode funcionar unicamente uma integração econômica européia.

Com base nesta perspectiva, a promoção da Europa social surge como uma condição necessária para o processo de integração européia. Ao mesmo tempo, é um elemento essencial do Direito constitucional comum europeu (cfr. sobre este conceito, HÄBERLE, P., 1991) enquanto formulação constitucional comum aos Estados membros da União. Não seria compreensível que o processo de integração européia se assentasse sobre abordagens constitucionais alheias àquelas que fazem parte dos ordenamentos dos países membros. Partindo da idéia das tradições constitucionais comuns, não seria aceitável um Direito constitucional europeu no qual o princípio do Estado social estivesse ausente.

\section{CONSTRUÇÃO E “DESCONSTRUÇÃO” DO ESTADO SOCIAL}

\subsection{O Estado social como forma estatal}

O Estado social e democrático de direito é um princípio estruturante da Constituição. Um princípio que sintetiza a transformação essencial do Estado liberal (legal) de Direito em Estado social (constitucional) de Direito. Após sua gênese histórica podemos ver o grande pacto social que, como H. HELLER indicava, em 1929, supunha a alternativa à ditadura. O ponto de partida deve ser encontrado num Estado democrático no qual se reconheça o pluralismo social, que se articula através de uma formulação constitucional consensuada entre os diversos setores sociais. Este consenso, que dá lugar a um autêntico direito constitucional, a uma Constituição normativa, só é possível mediante a integração dos diversos interesses em pugna, acolhida pela fórmula do Estado social. À semelhança da própria normatividade da Constituição o Estado social foi necessário e, ao mesmo tempo, possível, pela transformação democrática do Estado suscitada pela extensão do sufrágio, manifestada de maneira substantiva no período entre-guerras. Justamente neste período, sendo já necessário não foi, no entanto, possível, pela incapacidade dos setores em conflito em chegar a um acordo constitucional. Foram assim proféticas as palavras de H. HELLER: a alternativa era Estado social ou ditadura.

Nas palavras de GARCÍA PELAYO, o Estado social é "uma forma estatal que se corresponde historicamente com a etapa do neocapitalismo ou capitalismo tardio" (GARCÍA PELAYO, M., 1975, p. 66). O Estado social é uma forma de Estado perfeitamente reconhecível como tal, ainda que construída sobre a matriz do Estado liberal (LÓPEZ Y LÓPEZ, A.M., 1996, p. 430), razão pela qual assume esta ordenação 
constitucional. Na realidade, o Estado social, como indica GARCÍA PELAYO, não nega os valores do Estado liberal de Direito, mas lhes dá novo significado e os complementa com outros critérios axiológico-políticos, de tal maneira que se pode dizer que com base nesta concepção "a liberdade política é irreal se não está acompanhada da liberdade das dependências econômicas; que a propriedade há de ter como limite sua funcionalidade para os sistemas social e econômico e os direitos dos que a tornam produtiva; que a segurança não se estende só à dimensão jurídica senão à dimensão existencial em geral; que a igualdade não pode ser considerada como tal unicamente ante a lei, senão que deve se estender, na medida do possível, às cargas e benefícios, e que a participação se amplia aos bens e serviços e às formas de democracia social” (GARCÍA PELAYO, M., 1975, pp. 55-56).

Na fórmula Estado social e democrático de Direito, o Estado social se integra como um elemento essencial, razão pela qual, como já indicamos anteriormente, sua transformação pode incidir também na alteração da própria fórmula (DE CABO, C., 1986, pp. 10, 57; 1993, p. 28). Isto não quer dizer, me parece, que o Estado social seja um componente necessário de uma ordenação democrática e jurídica do Estado em qualquer sociedade e momento histórico. Porém, assim se caracteriza, ao menos, na atualidade, na percepção que se tem, nas constituições normativas da Europa, da democracia pluralista e da normatividade constitucional. O princípio do Estado social se infiltrou expressamente nos textos constitucionais e/ou na cultura constitucional européia, de tal modo que a percepção de elementos essenciais desta cultura constitucional (como o sistema de direitos e liberdades) só se compreende se se considera este princípio.

\subsection{Estado social e Estado de direito}

A incompatibilidade entre Estado social e Estado de direito seria predicada por alguns autores para questionar a viabilidade constitucional do Estado social e suas possibilidade de realização prática. Exemplo paradigmático destas abordagens temos em FORSTHOFF, para quem o Estado social é obra da legislação e da administração, porém não é suscetível de ser integrado na estrutura constitucional pela sua incompatibilidade com o Estado de direito (mais além da via indireta do exercício do poder tributário do Estado, que sim seria suscetível de uso constitucional por mostrar-se compatível com o Estado de Direito). Para este autor, é possível dissociar os elementos constitutivos do Estado de Direito da base sociológica da qual surgiram, de tal maneira que estes elementos, conformam um conceito, por assim dizer, universal e abstrato de Estado de Direito. Este conceito formulado de maneira rígida não permite a inserção do Estado social nas suas estruturas. No mais, lhes priva na realidade de tal condição garantista e à constituição de seu caráter de constituição social (FORSTHOFF, E. 1975, pp. 77 e ss.)

O caráter intensamente ideológico destas abordagens não precisa ser destacado. Como indica A. LÓPEZ, é inaceitável a suposta fungibilidade histórica do Estado social ante "uma suposta falta de contingência histórica do chamado Estado de Direito com menosprezo pela sua concreta origem no tempo e de suas concretas funções ideológicas” (LÓPEZ Y LÓPEZ, A.M., 1996, p. 430). Esta pretensão de dotar o Estado de Direito de um caráter universal e “ahistórico” (na realidade o Estado liberal 
de Direito) não resiste a uma mínima comparação com a realidade constitucional, pese às taxativas afirmações de FORSTHOFF, de que "a impossibilidade de configurar estruturalmente o Estado social no quadro de uma constituição segundo o modelo do Estado de Direito se manifesta em todas as Constituições do mundo promulgadas depois de 1945” e de que “a fórmula do Estado Social de Direito não é um conceito jurídico no sentido de designar uma categoria especial de Estado de Direito, com características específicas e conteúdo material próprio” ((FORSTHOFF, E. 1975, pp. 101 e 97).

No mais, tampouco se pode levantar o princípio de segurança jurídica como um obstáculo ao princípio do Estado social, partindo da contradição e do conflito inevitável entre Estado de direito e Estado social (como faz DOEHRING, K., 1978, pp. 122 e ss.). Pelo contrário, o Estado social de Direito exige não um conceito estático ou rígido, e sim uma concepção dinâmica do princípio de segurança jurídica (LUCAS VERDÚ, P., 1975, pp. 118-9).

A pretensão de contrapor como incompatíveis o Estado social e o Estado de Direito pode se considerar algo já superado, ao menos na doutrina alemã da qual partiu com tanta intensidade (cfr. BENDA, E., 1994, p. 526). Uma nova frente se abre agora, no entanto, como adiantávamos na Introdução, e como veremos seguidamente, no que concerne à relação entre ambos princípios. Já não se trata de incompatibilidade senão, ao contrário, da possibilidade de que o Estado de Direito funcione como limite ante as pretensões de desmonte do Estado social. A questão deixa de ser paradoxal, a não ser que a contemplemos a partir do inevitável processo histórico que gerou direitos cuja limitação pode resultar tão problemática como foram outrora as limitações à propriedade.

\subsection{A defesa do Estado social}

A situação atual do Estado social é peculiar, pois o debate não se concentra tanto na ativação do princípio quanto na sua defesa estática ante as políticas estatais orientadas à sua desativação. A questão chave aqui é se o princípio do Estado social garante ou não as conquistas sociais já logradas, de tal modo que se possa falar de um solo mínimo consolidado e inalterável. Volta-se assim, de outro modo, à polêmica jurídico-constitucional que se desenvolveu com motivo da implantação do Estado social, quando se opunham às políticas sociais razões de segurança jurídica e de vulnerabilidade de direitos adquiridos. Certamente, parece estranho um tratamento constitucional do princípio do Estado social centralizado na defesa dos direitos associados a este princípio. No entanto, a partir desta perspectiva, também se pode considerar um avanço histórico do princípio esta percepção “conservadora” que seria inconcebível há cem anos.

Em todo caso, a resposta constitucional a esta questão não pode ser, sob a perspectiva de uma constituição consensuada na qual se respeitem ao menos os núcleos indisponíveis das diversas instituições (BALAGUER, F., 2001-II), mais que a de aceitação de uma certa reversibilidade das políticas sociais. Não é possível congelar fora do tempo e do espaço nenhum princípio ou direito, nem sequer o Estado social ou os direitos sociais. A Constituição não pode ser entendida como uma linha de defesa estática do princípio do Estado social, nem da transformação dos 
perfis deste deriva-se necessariamente uma mutação constitucional. Aplicar a idéia de mutação constitucional às transformações no Estado social (cfr. PÉREZ AYALA, A., 1997, p. 335) pode revelar-se algo problemático (APARECIDO PÉREZ, M.A., 1993, p. 58). Certamente, o Estado de Direito continua sendo um modelo de convivência válido (CARMONA CUENCA, E., 2000, p. 198); porém é algo mais que isto: é uma formulação constitucional que deve ser respeitada ou modificada através dos mecanismos de reforma estabelecidos para tal efeito.

Sob a Constituição de 1978 tem havido e haverá diferentes configurações dos direitos, fruto da capacidade de ordenação do legislador e da diferente percepção que o tempo introduzirá na concepção de cada direito. Como limite funciona sempre o respeito ao conteúdo essencial e à normatividade da Constituição. Nestas condições, pode-se dizer que há sim um solo mínimo do princípio do Estado social, como há também do Estado de Direito ou do Estado democrático. Porém esse solo não está formado necessariamente, por todas e cada uma das instituições e pelas medidas concretas que atualmente possam se adscrever a cada um destes princípios. A Constituição não contêm uma garantia dos níveis de prestações alcançados pelo Estado social (GARCÍA HERRERA, M.A., MAESTRO BUELGA, G., 1988, p. 105). Os retrocessos são, portanto, constitucionalmente possíveis, contanto que se inscrevam dentro da capacidade de configuração do legislador. Porém, o respeito ao pluralismo político e à possibilidade de alternância no poder que decorre do mesmo não significa que o princípio do Estado social não tenha que ser preservado. Como indica L. PRIETO SANCHÍS, há um núcleo irredutível dos direitos sociais que representa um conteúdo intangível para a liberdade de configuração do legislador (PRIETO SANCHÍS, L., 1995, p. 54).

São propostas aqui questões especialmente delicadas se atendemos aos mandatos e limitações dos poderes públicos contidos na Constituição para tornar possível a realização e a sobrevivência do Estado social. A supressão de medidas concretas orientadas à realização do Estado social não tem necessariamente que ser considerada contrária à Constituição. O legislador tem que tornar possível a realização de múltiplas normas constitucionais que lhe impõem mandatos, podendo modificar a ordenação legislativa dentro de certos limites. Cabe considerar ademais que, partindo de uma perspectiva dinâmica, determinadas medidas de promoção podem demonstrar-se desnecessárias com o passar do tempo e que a permanência de outras pode dificultar atuações mais urgentes ou mais necessárias no âmbito social. Sirvam como exemplo destas últimas, na Espanha, as medidas para prevenir a violência doméstica ou para atender as necessidades básicas dos imigrantes, que (caso se queira afrontar seriamente) requererão um crescente esforço financeiro dos poderes públicos.

Em relação ao anterior, não cabe ignorar tampouco que, em matéria social, as medidas que devem ser adotadas carecem de um insumo econômico por parte dos poderes públicos e que o argumento orçamentário pode ser utilizado para legitimar o recorte destas medidas ou a inércia do poder público. Também neste ponto, a intervenção do Tribunal Constitucional no controle de constitucionalidade se apresenta como especialmente delicada. Para começar, esta intervenção não é possível quando falamos simplesmente de inércia estatal. Questão distinta se propõe quando se produz 
uma hipótese de inconstitucionalidade por omissão parcial, consequência de uma discriminação levada a cabo pelo legislador. Não obstante, também neste último caso o Tribunal Constitucional tem que ser prudente para não incrementar as cargas financeiras do poder público, admitindo a possibilidade de que o legislador altere no futuro a configuração estabelecida, sempre que respeite o princípio de não discriminação.

No entanto, reconhecendo os riscos implicados na intervenção do Tribunal Constitucional nesta matéria, também parece claro que uma não fiscalização da política social e inclusive da política econômica do Estado provoca uma considerável diminuição da força normativa da Constituição num Estado social e democrático de Direito. Se o artigo 31.1 CE contêm um mandato de progressividade do sistema tributário (que não deixa de ser uma opção em relação a distribuição dos recursos sociais, na fase de sua obtenção pelo poder público), um descumprimento frontal deste mandato (como já parece estar ocorrendo, se consideramos que desde 1999, a arrecadação de impostos indiretos na Espanha supera a procedente de impostos diretos: cfr. o diário El País de 11 de novembro de 2000) não deveria ser aceito pelo Tribunal Constitucional, se a questão se propusesse ante este órgão. Se a política econômica está claramente desenhada contra o princípio do Estado social, a maioria no poder não pode pretender a convalidação constitucional de suas medidas baseando-se numa insuficiência dos meios financeiros que nada mais é do que o resultado de uma determinada opção pela distribuição dos recursos. Assim por exemplo, o Estado social não pode ficar reduzido, como parece ser tendência atual, a um Estado assistencial, ao qual "se atribui como função básica do sistema de proteção, a intervenção ante as situações de indigência, perdendo força e virtualidade o modelo constitucional de direitos sociais” (GARCÍA HERRERA, M.A., MAESTRO BUELGA, G., 1999, p. 244). Esta tendência supõe uma clara desnaturalização do princípio constitucional. Como indica GOMES CANOTILHO, os problemas de financiamento não podem implicar o grau zero de vinculação jurídica dos direitos fundamentais sociais (GOMES CANOTILHO, J.J., 1998, p. 45). A este respeito, não cabe dúvida de que estes problemas de financiamento podem ser inequivocamente aliviados, sem necessidade de mudar o sistema econômico nem a política econômica, se existe vontade por parte dos poderes públicos em obter meios financeiros que tornem possível a realização de políticas sociais. O recente episódio das distintas fórmulas de concessão de licenças de telefonia celular a companhias telefônicas, com uma arrecadação tão distinta em diferentes países europeus, nos demonstra isso.

O anterior não é obstáculo para reconhecer que a orientação social da política estatal depende basicamente da decisão dos cidadãos manifestada através das eleições democráticas. É, portanto, uma questão de natureza política que não pode descansar sobre mandatos constitucionais. Pelo contrário, este manto protetor constitucional pode engendrar um efeito desmobilizador que contribua ainda mais para favorecer os recortes sociais. A este respeito, cabe recordar aqui, conforme DOGLIANI, que justamente o êxito do Estado social, ao gerar segurança, produziu uma desmobilização das atitudes militantes que haviam contribuído para sua construção (DOGLIANI, M., 1997, p. 688). Uma desmobilização similar pode se produzir, me parece, se esta sensação de segurança se produz como consequência da fé posta no texto constitucional, como 
se da mera proclamação dos direitos se deduzisse sua existência prática sem necessidade de realizar esforço social e político algum. Isto não é óbice, como parece lógico, para a utilização discursiva do forte componente social contido na Constituição Espanhola a efeitos de legitimar a reivindicação política dos direitos sociais.

\section{OS PERFIS CONSTITUCIONAIS DO ESTADO SOCIAL}

\subsection{O estabelecimento constitucional do Estado social}

A opção constitucional pelo Estado social e democrático de Direito se manifesta, antes do art. 1.1, no Preâmbulo da Constituição Espanhola. Com efeito, ali se expressa claramente a vontade da Nação espanhola de "garantir a convivência democrática dentro da Constituição e das leis conforme uma ordem econômica e social justa”, de “consolidar um Estado de Direito que assegure o império da lei como expressão da vontade popular", de "promover o progresso da cultura e da economia para assegurar a todos uma qualidade de vida digna”, assim como de "estabelecer uma sociedade democrática avançada”.

Vale também destacar que o artigo 1.1 (incluído na "norma de abertura" da Constituição na expressão de P. LUCAS VERDÚ, 1983, pp. 37 e ss.) não se limita a reproduzir a fórmula do Estado social e democrático de Direito, antes assume um conteúdo mais denso, ao incorporar os valores superiores do ordenamento que têm uma estreita conexão com ela: "Espanha se constitui num Estado social e democrático de Direito, que propugna como valores superiores de seu ordenamento jurídico a liberdade, a justiça, a igualdade e o pluralismo político”.

O preceito constitucional seguinte no qual transparece o estado social é o artigo 2, pois ali se "reconhece e garante o direito à autonomia das nacionalidades e regiões que a integram e a solidariedade entre todas elas”. Certamente, a autonomia das Comunidades Autônomas não é uma manifestação do princípio do Estado social. No entanto, o Estado autonômico constitui um âmbito de projeção muito importante do Estado social que transparece dentro e fora do Título VIII CE dedicado à Organização Territorial do Estado. Em realidade, a estruturação autonômica do Estado é um princípio metodológico ineludível para a análise constitucional em muitos âmbitos (BALAGUER, F., 2001-I) e, entre estes, o do Estado social não é menos importante.

A projeção do Estado social sobre o Estado autonômico já se manifesta na distribuição competencial operada pela interrelação Constituição-Estatutos de Autonomia em relação às competências mais estreitamente relacionadas com a realização de políticas sociais (que são uma parte do princípio do Estado social). A Constituição torna possível a assunção por parte das Comunidades Autônomas de competências em matérias de grande importância para estes fins. Assim, em razão do artigo 148.1, na ordenação do território, urbanismo e habitação, gestão em matéria de proteção do meio ambiente, fomento à cultura, promoção do esporte e da adequada utilização do ócio, assistência social, saúde pública e higiene. Por sua parte, o 149.1 possibilitou a assunção de competências sobre outros âmbitos materiais por parte das Comunidades Autônomas ou a ampliação do nível de faculdades contempladas pelo art. 148.1: saúde pública e seguridade social, meio ambiente, educação, entre outros. 
Além da distribuição competencial, que dá lugar ao reconhecimento do pluralismo territorial na realização do Estado social (o que abre um sem número de perspectivas políticas e constitucionais (Cfr. LUCAS MURILLO, P., 1984 e 1993; BALAGUER, F., 1992; CRUZ VILLALÓN, P., 1993; PÉREZ VILLALOBOS, M.C., 2002) o Estado social se projeta também em princípios constitucionais que orientam a ação de todos os poderes públicos. Tratam-se de princípios que nascem juntamente com o do Estado social que promovem a equiparação entre diversos territórios do Estado (40.1, 131.1, 138.1 CE), que obrigam à realização da solidariedade (2, 138.1, 156.1, 158.2 $\mathrm{CE})$, ou que estabelecem proibições e limites (138.2, 139.1 e 2, 157.2 CE). De especial interesse se configura já não o princípio de igualdade de trato estabelecido no artigo 139.1 ("Todos os espanhóis têm os mesmos direitos e obrigações em qualquer parte do território do Estado”), e sim, sobretudo, o de igualdade de status do artigo $149.1 .1^{\circ}$, preceito através do qual se atribui ao Estado a competência sobre “a regulação das condições básicas que garantam a igualdade de todos os espanhóis no exercício dos direitos e no cumprimento dos deveres constitucionais”.

Um preceito chave para a compreensão do alcance do princípio do Estado social é o artigo 9.2 CE, no qual se estabelece que "Corresponde aos poderes públicos promover as condições para que a liberdade e a igualdade do indivíduo e dos grupos nos quais se integram sejam reais e efetivas; remover os obstáculos que impeçam ou dificultem sua plenitude e facilitar a participação de todos os cidadãos na vida política, econômica, cultural e social”. Este preceito expressa, sem dúvida, o sentido "forte" do Estado social, enquanto tal princípio tenha este sentido. Como indica J. JIMÉNEZ CAMPO, nele se afirma “a primazia da política sobre a economia” (JIMÉNEZ CAMPO, J. 1984, p. 279). Porém, não podemos desconhecer que é também o mais controvertido e de mais difícil realização prática porque implica a criação de condições que tornem possível uma transformação social qualitativa.

É também manifestação do Estado social o princípio de dignidade reconhecido no artigo 10.1 CE (“A dignidade da pessoa, os direitos invioláveis que lhe são inerentes, o livre desenvolvimento da personalidade, o respeito à lei e aos direitos dos demais são fundamento da ordem política e da paz social”). Naturalmente este princípio poderia ser reconhecido constitucionalmente sem implicar o do Estado social. No entanto, sua realização exige o estabelecimento de condições materiais dentro das quais a dignidade da pessoa seja possível. Partindo desta perspectiva, dignidade da pessoa e Estado social aparecem numa relação de interação recíproca ao menos sob as condições econômicas e sociais de nossa ordem constitucional.

Outro preceito que afeta diretamente o Estado social é o artigo $14 \mathrm{CE}$, em virtude do qual "Os espanhóis são iguais ante a lei, sem que possa prevalecer qualquer discriminação em razão do nascimento, raça, sexo, religião, opinião ou qualquer outra condição ou circunstância pessoal ou social”. O princípio de igualdade formal reconhecido neste artigo usualmente se contrapõe ao de igualdade substancial ou material do artigo 9.2 CE. A relação entre ambos é, a princípio, conflitiva. Entretanto, como veremos mais adiante, existe também uma relação de convergência que tem feito com que o Tribunal Constitucional utilize o princípio de não discriminação do artigo 14 em favor da realização da igualdade material do artigo 9.2. 
A partir de todos estes princípios recepcionados pela Constituição, o texto constitucional passa ao reconhecimento de direitos de distinta natureza e alcance. A projeção do Estado social sobre os direitos e liberdades não suscita, de antemão, uma questão metodológica como é a de se devemos aceitar pacificamente as categorias habituais de caracterização dos direitos sociais, diferenciando entre os clássicos direitos de resistência e os direitos de prestação. Realmente haveria que se opor aqui, como P. HÄBERLE, a uma abordagem rígida, encastelada, que dificilmente pudesse dar conta da realidade atual dos direitos e liberdades (HÄBERLE, P., 1999). A partir desta perspectiva parece mais adequado entender que o Estado social se projeta sobre todos e cada um dos direitos, com diversa intensidade, pois a realização dos direitos exige a atividade dos poderes públicos.

Certamente, isto não quer dizer que todos os direitos estejam equiparados pela Constituição no seu nível de garantias. Antes, as garantias dos direitos vão perdendo força já na Segunda Seção do Capítulo II do Título I (em relação à Primeira) e perdem ainda mais no Capítulo III, onde estão contidos os princípios orientadores da política social e econômica, nos quais o princípio do Estado social se manifesta em sua maior amplitude. Os mecanismos de proteção dos direitos são mais intensos em relação aos conteúdos da Seção Primeira: procedimento reforçado de reforma (art. $168 \mathrm{CE}$ ); exigência de lei orgânica para sua aprovação (art. $81 \mathrm{CE}$ ); previsão de um procedimento preferencial e sumário para sua proteção jurisdicional, junto com o princípio de igualdade do art. 14 (e, por reconhecimento legal, a objeção de consciência do art. 30) (art. $53.2 \mathrm{CE}$ ); possibilidade de promover recurso de amparo ante o TC para a proteção destes direitos (art. 53.2 CE). Seguem este grupo de direitos, no que tange ao nível de proteção, os incluídos na Seção Segunda: todos os direitos do capítulo segundo (nas suas duas seções), gozam das seguintes garantias: vinculação direta de todos os poderes públicos, sem necessidade de desenvolvimento legislativo prévio (art. 53.1 CE); reserva de lei para a regulação destes direitos (orgânica no caso da seção primeira) (art. 53.1 CE); obrigação do legislador em respeitar o conteúdo essencial destes direitos (art. 53.1 CE).

Por sua parte, os princípios norteadores do capítulo III gozam de uma proteção menor. Segundo a previsão do art. 53.3 da Constituição, "O reconhecimento, o respeito e a proteção dos princípios reconhecidos no capítulo III, informará a legislação positiva, a prática judicial e a atuação dos poderes públicos. Somente poderão ser alegados ante a Jurisdição ordinária de acordo com o que disponham as leis que os desenvolvam”. Estes direitos requerem, portanto, desenvolvimento legislativo para assegurar seu exercício por parte dos cidadãos. Isto não significa uma depreciação do seu valor normativo, antes implica tão só que a vinculação essencial entre estes direitos e o ordenamento se concentra sobretudo na sua eficácia em relação ao legislativo. Eficácia que se manifesta também em relação aos outros poderes do Estado, na medida em que as normas deverão ser interpretadas em conformidade com a Constituição e portanto, também em conformidade com os princípios norteadores do capítulo III. Deve-se considerar ademais, que os direitos do capítulo III são também direitos constitucionais, e gozam, portanto, das garantias comuns a todo direito constitucional. Entre elas cabe incluir as seguintes: a proteção que decorre da 
existência de um TC com capacidade para julgar a conformidade das leis com os preceitos constitucionais relativos a direitos e liberdades, por meio do controle de constitucionalidade das leis; a vinculação de todos os juízes e tribunais ordinários aos direitos e liberdades constitucionais, e, em especial, à realização de uma interpretação das normas infra-constitucionais favorável sempre aos direitos constitucionais; a instituição do Defensor do Povo (art. $54 \mathrm{CE}$ ); a instituição do Ministério Público (art. $124 \mathrm{CE}$ ).

O Estado social se manifesta, por último, no Título VII, sobre Economia e Fazenda, no qual estão contidos princípios essenciais tais como a declaração do artigo 128.1 CE, na qual se lê que "Toda a riqueza do país nas suas distintas formas e seja qual for sua titularidade está subordinada ao interesse geral”, ou o reconhecimento da iniciativa pública na atividade econômica do 128.2, assim como a possibilidade de reservar ao setor público recursos ou serviços essenciais e acordar a intervenção de empresas da mesma ordem. Especialmente relevante é o artigo 129.2, que reza que “Os poderes públicos promoverão eficazmente as diversas formas de participação na empresa e fomentarão, mediante uma legislação adequada, as sociedades cooperativas. Também estabelecerão os meios que facilitem o acesso dos trabalhadores à propriedade dos meios de produção”. Este última parágrafo é realmente revolucionário, apesar de que sua incorporação à Constituição tenha sido promovida por parlamentares da Aliança Popular (cfr. GALLEGO-DÍAZ, S./DE LA CUADRA, B., 1989, pp. 45-6). Cabe destacar também, dentro deste Título, a habilitação conferida ao Estado para planificar mediante lei a atividade econômica geral, para atender as necessidades coletivas e estimular o crescimento da renda e da riqueza e sua distribuição mais justa, assim como a previsão de que o Conselho Econômico e Social colabore com o Governo na elaboração dos projetos de planificação (131.1 e 2). Como se pode ver, neste Título estão contidos tanto aspectos instrumentais do Estado social, que permitem ampliar a esfera de ação dos poderes públicos, quanto princípios de ordem material em prol de uma transformação qualitativa do sistema econômico.

Em termos gerais, no estabelecimento constitucional do Estado social, poderíamos diferenciar diversos aspectos:

$1^{\circ}$ Os preceitos relacionados com a procura existencial, com a provisão por parte dos poderes públicos das condições materiais necessárias para subsistência.

$2^{\circ}$ Os preceitos relacionados com a transformação social em favor de uma maior igualdade de oportunidades e igualação social.

$3^{\circ}$ Os preceitos relacionados com intervenções do Estado que têm uma função corretora do estrito mecanismo econômico em favor de princípios e direitos de natureza social.

A diversidade de desenvolvimentos constitucionais do Estado social se corresponde também com uma heterogeneidade de elementos conformadores deste princípio. As prestações baseadas em critérios contributivos são parte do Estado social, assim como as de caráter assistencial. Contudo, nenhuma delas se assenta nitidamente sobre princípios básicos da ordem constitucional tais como o de dignidade. Uma atividade prestacional desta natureza deveria se assentar sobre um princípio de igualdade de 
todos os cidadãos, de tal maneira que a saúde ou a seguridade social proporcionadas pelo seguro-desemprego ou as pensões por aposentadoria não dependessem de prévia contribuição econômica realizada pelo trabalhador. Em realidade, o mecanismo contributivo se parece muito com o seguro privado, salvo no que concerne às maiores garantias (e também às maiores limitações) derivadas de seu caráter público.

As propostas de igualação social têm uma maior vinculação com o princípio constitucional do Estado social. Todavia, estas políticas também podem proceder de orientações que não são sempre passíveis de serem incluídas no princípio de dignidade da pessoa. Isto ocorre, por exemplo, quando se tenta parcializar a igualação social focalizando-a em setores concretos. Pretende-se assim a validade de soluções parciais que tornem possível somente a igualação de determinadas coletividades. Partindo desta perspectiva, não se promove uma realização plena do princípio constitucional, senão uma reivindicação específica para os problemas destas coletividades. Frente a estas abordagens, cabe defender uma realização homogênea da igualdade substancial que é a única compatível com este princípio constitucional.

\subsection{O tratamento jurisprudencial do estado social}

O desenvolvimento do princípio do estado social, assim como o de outros princípios constitucionais, corresponde sobretudo ao legislador (PEREZ ROYO, J., 1995, p. 2926). Não é, logicamente, função da jurisdição constitucional projetar políticas de realização do Estado social. Pelo contrário, o Tribunal Constitucional tem que precisar os contornos e os limites da ação legislativa para torná-la compatível com a ordem constitucional. Não obstante, deste modo se constrói também a imagem constitucional do Estado social, tanto no que se refere ao que o legislador não pode fazer quanto por aquilo que ele está obrigado a fazer.

A jurisprudência constitucional usou freqüentemente a fórmula "Estado social de Direito" ou "Estado social e democrático de Direito", se bem que não se pode extrair deste uso uma determinação constitucional do princípio equiparável ao de outras instituições e princípios. Pelo contrário, como indica M.A., APARICIO, este uso tem um caráter meramente argumentativo, de tal modo que "o TC não parte de uma definição do conteúdo do Estado social e democrático de Direito. O que faz é utilizar esta fórmula como meio de concreção ou interpretação de outros preceitos constitucionais ou, melhor dito, concreta o preceito ou preceitos analisados em cada caso, lhe dá um sentido determinado e, em seguida, imputa este sentido ao conteúdo geral da fórmula” (APARICIO, M.A., 1993, p. 61). Certamente, este modo de operar é difícil de evitar porque a fórmula constitucional é o produto de uma sedimentação de diversos elementos, heterogêneos e potencialmente contraditórios. Daí que seja a interação de cada um destes elementos com a fórmula mesma o que acabe por determinar seu sentido. Esta concreção não se pode realizar de maneira estática e isolada, senão de modo dinâmico e relacional, como ocorre com outros institutos constitucionais (singularmente o de garantia do conteúdo essencial dos direitos, cfr. BALAGUER, F. 2001-II). O Tribunal Constitucional trabalha aqui com uma metodologia que está estreitamente relacionada com as exigências derivadas da Constituição do pluralismo. 
Não cabe esperar, portanto, que possamos ter uma imagem fixa do Estado social e democrático de Direito como a que podemos ter, por exemplo, da Monarquia Parlamentar. Pelo contrário, mais que a um conteúdo pré-estabelecido, o princípio do Estado social e democrático de Direito apela a uma fórmula de contornos elásticos, que se concretam no momento em que se tem que resolver os problemas jurídicoconstitucionais.

Em todo caso, a análise jurisprudencial do Estado social vai muito mais além da doutrina constitucional sobre o artigo 1.1 CE. Entretanto, não nos interessam aqui as formulações jurisprudencias relativas aos diversos preceitos constitucionais nos quais o princípio do Estado social se estabelece. Mas da jurisprudência constitucional há dois aspectos gerais que devem ser analisados: a questão relativa à reversibilidade das prestações sociais e a relativa à consecução da igualdade substancial. Em ambas as questões manifesta-se de maneira global o estado social na sua ativação ou realização e em sua eventual desativação. São, portanto, questões relativas à eficácia normativa do Estado social como princípio constitucional.

No que se refere ao primeiro aspecto, não cabe dúvida que o Tribunal Constitucional admite a reversibilidade das conquistas sociais. Não as admite, no entanto, de maneira incondicionada e ilimitada. Para começar, é necessário justificar a redução das prestações sociais. Assim afirmou de início na STC 81/1982, em cujo FJ 3 se diz que "Dada a conclusão à que se chegou nos parágrafos anteriores, surge um segundo problema que é o mecanismo que se utilizou para reestabelecer a igualdade, pois como já expusemos mais acima, pode se privar a mulher da condição privilegiada que num momento anterior lhe foi concedida ou pode se ampliar o conteúdo dos direitos do homem para que chegue a possuir o mesmo alcance. Dado o caráter social e democrático do Estado de Direito erigido por nossa Constituição e a obrigação, imposta ao Estado pelos arts. 9.2 e 35 da Constituição, de promover as condições para que a igualdade dos indivíduos e dos grupos sejam reais e efetivas e a promoção através do trabalho, sem que em nenhum caso possa se incorrer em discriminação em razão de sexo, deve se entender que não se pode privar o trabalhador das conquistas sociais já conseguidas, sem razão suficiente para isto. Desta maneira, no presente caso, não se deve reestabelecer a igualdade privando ao pessoal feminino dos benefícios que no passado tivessem adquirido, senão outorgando os mesmos ao pessoal masculino que realiza trabalhos e atividade profissional idênticos, sem prejuízo de que no futuro o legislador possa estabelecer um regime diferente do atual, sempre que respeite a igualdade entre os trabalhadores”. Além desta limitação formal que obriga a expressar as razões da redução das prestações sociais, existe outra limitação de caráter material. Com efeito, as possibilidades de redução não são ilimitadas, pois o legislador deve respeitar sempre um núcleo mínimo que é indisponível. Assim declarou o TC em relação ao regime público de seguridade social (STC 37/1994m FJ 3: “O art. 41 CE impõe aos poderes públicos a obrigação de estabelecer - ou manter - um sistema protetor que se corresponda com as características técnicas dos mecanismos de cobertura próprios de um sistema de Seguridade Social. Noutros termos, o preceito referido consagra em forma de garantia institucional um regime público “cuja preservação se julga indispensável para assegurar 
os princípios constitucionais, estabelecendo... um núcleo ou reduto indisponível pelo legislador" (STC 32/1981, fundamento jurídico 3.), de tal sorte que há de ser preservado "em termos reconhecíveis para a imagem que da mesma tem a consciência social em cada tempo e lugar” (STC 26/1987, fundamento jurídico 4., e 76/1988, fundamento jurídico 4.)”. Não há, portanto, de acordo com a jurisprudência constitucional, nem cristalização das prestações sociais nem liberdade do legislador para desmantelar o Estado social.

No que concerne à promoção do Estado social por meio da realização efetiva do princípio de igualdade substancial, indicamos anteriormente que a igualdade material e a igualdade formal não foram contempladas pelo TC somente de forma contraditória. Certamente, na tensão tradicional entre ambos os termos, o TC recorreu ao mandato de igualdade substancial do 9.2 para modular a igualdade jurídica do 14 , admitindo a legitimidade constitucional de medidas legislativas que não se considerem discriminatórias na medida em que estejam amparadas pelo 9.2 (e inaplicando, portanto, a proibição de discriminação do artigo 14 para tornar possível a igualdade material). Mas é possível encontrar também relações de convergência entre o artigo 14 e o 9.2, de tal maneira que em determinados contextos normativos, a igualdade formal torna possível, mediante sua aplicação, a igualdade material. Isto pode ocorrer, por exemplo, para que determinados atos normativos mantenham ao longo do tempo desigualdades fáticas que gerem uma desigualdade jurídica constitucionalmente proibida (cfr. MONTILLA MARTOS, J.A., 1997, pp. 455 e ss.). Também, naquelas hipóteses nas quais o Tribunal Constitucional estende determinados direitos ou benefícios sociais a grupos não incluídos pelo legislador, apelando à proibição de discriminação do artigo 14. Desta maneira, pretensões de igualdade substancial podem ser formuladas como posições subjetivas amparando-se no direito à igualdade formal (cfr. PRIETO SANCHIS, L., 1995, pp. 18, 31 e ss.). No entanto, não se pode ignorar que a utilização do artigo 9.2 CE como preceito gerador de direitos é muito limitada (cfr. PRIETO SANCHIS, L., 1995, pp. 31 e ss.; MONTILLA MARTOS, J.A., 1997, pp. 455 e ss.).

\section{CONCLUSÕES}

1. A análise do Estado social (do Estado social e democrático de Direito) deve incorporar referentes econômicos, sociais e políticos, dentro de seu tratamento constitucional. Estes aspectos devem se integrar no discurso jurídico-constitucional. A Constituição não é, porém, um elemento a mais deste discurso, senão o ponto de referência em torno do qual o próprio discurso pretende se articular. Não é aceitável, partindo desta perspectiva, uma abordagem "economicista” que outorgue um predomínio absoluto aos fatores econômicos. Este tipo de abordagens se inscreve dentro da forte tensão ideológica à qual está submetido o Estado social. A este respeito, cabe ressaltar como as primeiras linhas de defesa frente à implantação do Estado social, foram essencialmente jurídicas e baseadas numa presumida incompatibilidade entre Estado social e Estado de Direito. A ciência jurídica significou um freio muito limitado à pressão política que deu origem ao grande pacto que na Europa consagrou a fórmula do Estado social. Para desarticulação do Estado social, buscou-se uma metodologia mais eficaz: a ciência econômica, que recupera os termos deterministas 
do racionalismo universalista expondo como verdades absolutas e inevitáveis os postulados do modelo econômico vigente e inclusive de uma determinada política econômica.

2. O Estado social, enquanto expressão de um pacto entre diversos agentes sociais não é uma fórmula homogênea razão pela qual, à semelhança do que ocorre com a Constituição (embora em menor medida) inexiste uma imagem comum do Estado social, e sim distintas concepções. Estas concepções oscilam entre a garantia de uma mínima procura existencial voltada basicamente para evitar conflitos sociais excessivamente graves que pudessem por em perigo o sistema (o que, mais que um conceito de Estado social é uma deformação deste princípio constitucional) até propostas de transformação radical do modelo econômico. Estas últimas tendências se manifestam também na Constituição e são, portanto, uma opção constitucional válida. Não obstante, não se pode deixar de ressaltar, parafraseando aqui o mote de uma velha polêmica marxista, a dificuldade de estabelecer o "Estado social num só país”, concebido este a partir desta perspectiva de transformação radical do modelo capitalista, neste tempos de globalização e de interdependência econômica. No entanto, entre a mera atividade assistencial do Estado e a transformação social qualitativa há zonas de intervenção do Estado e de igualação social. A reivindicação destas políticas e sua ativação fazem parte também do significado histórico do Estado social como princípio nuclear de uma cultura constitucional de progresso, não só na promoção da igualdade como também da dignidade da pessoa.

3. O Estado social e democrático de Direito, sintetiza a evolução experimentada pelo constitucionalismo através do triplo processo de democratização, socialização e normativização. Partindo desta evolução pode-se entender como o Estado constitucional de Direito se conformou na Europa como um Estado social de Direito, de tal maneira que o trânsito do Estado legal de Direito ao Estado constitucional de Direito é também o do Estado liberal ao Estado social. A fórmula expressa uma coerência conceitual superadora de anteriores conflitos históricos: o Estado constitucional de Direito é, em virtude do consenso social sobre o qual se assentam as constituições normativas, um Estado social e um Estado democrático (no sentido de uma democracia representativa e pluralista). Sem estas duas conotações não seria possível falar de Estado de Direito no Estado constitucional das Constituições normativas: o reconhecimento do pluralismo social, da diversidade de interesses que dá lugar a um autêntico Direito constitucional se manifesta numas regras constitucionais que respondem à síntese consensuada entre os grupos que propugnam a transformação social e os que defendem a limitação da atividade estatal. Esta síntese se manifesta nas normas constitucionais dedicadas ao Estado social e é expressiva, em si mesma, de uma concepção da democracia que se assenta sobre o consenso e a integração.

4. O que há de afortunado na fórmula do Estado social e democrático de Direito e a ampla projeção do Estado social na Constituição deve ser contrastado com a pressão ideológica e política cada vez mais intensa em contra da realização deste princípio. A importância das abordagens “economicistas” favoráveis à desarticulação do Estado social se acrescenta devido ao processo de globalização que faz com que o desenvolvimento econômico dependa de instâncias externas ao Estado e portanto, ao 
âmbito da política e dos condicionamentos constitucionais. Porém, as limitações à capacidade de decisão política interna não são somente limitações ao Estado social senão também limitações ao Estado democrático. O poder econômico se desvincula assim em grande medida dos entraves impostos pelo poder político e começa a funcionar em grande parte como um poder autônomo insubmisso ao controle democrático. A lógica do mercado se impõe a qualquer outra consideração. Frente à expansão do "economicismo", torna-se cada vez mais necessária uma teoria constitucional do mercado (HÄBERLE). Na medida em que esta teoria constitucional se estenda a âmbitos geográficos cada vez mais extensos, existirão possibilidades de resistir ao efeito deste "economicismo" que pretende reduzir ao mínimo a política e as exigências constitucionais. A este respeito, não cabe dúvida de que o processo de integração européia é, ao mesmo tempo um risco, uma oportunidade para lutar contra as pretensões de determinação econômica dos espaços políticos e sociais. A integração européia pode significar assim (numa Europa social, democrática e constitucional), uma resposta em favor do espaço político e constitucional e contra o "economicismo”, ao permitir expandir estes espaços num âmbito supra-nacional no qual se possa resistir à incidência econômica da globalização.

5. A progressiva implantação do Estado social veio acompanhada da polêmica, hoje aparentemente superada, relativa a sua possível incompatibilidade com o Estado de Direito. Atualmente cabe questionar, no entanto, se o Estado de Direito não pode operar como limite ante as pretensões de desmonte do Estado social. A questão não deixa de ser paradoxal, salvo que a contemplemos a partir do inevitável decurso histórico que gerou direitos cuja limitação pode ser tão problemática como o foram outrora as limitações à propriedade. Porém, a resposta constitucional a este questionamento não pode ser, sob a perspectiva de uma constituição consensuada na qual se respeitem ao menos os núcleos indisponíveis das diversas instituições, mais que a de aceitação de uma certa reversibilidade das políticas sociais. Há, certamente, um solo mínimo do princípio do Estado social, como há também do Estado de Direito ou do Estado democrático. Porém este solo não está formado, necessariamente, por todas e cada uma das instituições e as medidas concretas que atualmente possam se adscrever a cada um destes princípios. A supressão de medidas específicas orientadas para a realização do Estado social não tem necessariamente que ser considerada contraria à Constituição. O legislador tem que tornar possível a realização de múltiplas normas constitucionais que lhe impõem mandatos, podendo modificar a ordenação legislativa dentro de certos limites. Cabe considerar ademais que, partindo de uma perspectiva dinâmica, determinadas medidas de promoção podem resultar desnecessárias com o decurso do tempo e que a permanência de outras pode dificultar atuações mais urgentes ou mais necessárias no âmbito social. Partindo desta perspectiva, não se pode ignorar o componente dinâmico incorporado ao princípio do Estado social.

6. A possibilidade de uma reconfiguração das políticas sociais e inclusive de uma certa reversibilidade das conquistas sociais não implica que a margem de ação do legislador neste âmbito não seja suscetível de controle jurisdicional. Ainda reconhecendo os riscos que estão implicados na intervenção do Tribunal Constitucional nesta matéria, também parece claro que uma não fiscabilidade da política social e 
inclusive da política econômica do Estado suscita uma diminuição considerável da força normativa da Constituição num Estado social e democrático de Direito. Se a política econômica está claramente desenhada contra o princípio do Estado social, a maioria no poder não pode pretender a convalidação constitucional de suas medidas baseando-se numa insuficiência de meios financeiros o que não é nada senão o resultado de uma determinada opção pela distribuição dos recursos. A este respeito parece claro que o Estado social não pode ficar reduzido a um Estado assistencial. Porém, a luta pelo Estado social é, basicamente, de natureza política, e não pode ser eludida partindo da exigibilidade dos mandatos constitucionais. Ao contrário, este manto protetor constitucional pode desenvolver um efeito desmobilizador que contribua ainda mais para favorecer os recortes sociais. Este efeito desmobilizador pode se produzir, se a fé posta no texto constitucional gera uma falsa segurança, como se da mera proclamação dos direitos se deduzisse sua existência prática sem necessidade de realizar qualquer esforço social e político. Isto não é óbice, logicamente, para a utilização discursiva do forte componente social contido na Constituição a efeitos de legitimar a reivindicação política dos direitos sociais.

7. A projeção constitucional do Estado social é amplíssima, não só pela grande quantidade de preceitos que são resultado direto deste princípio, como também pela incidência que o componente social tem na aplicação de outros princípios constitucionais. Exemplo disto podemos verificar num princípio como o de igualdade formal, em histórica tensão com o do Estado social e que não só cede na sua aplicação a exigências derivadas do princípio de igualdade material como, em determinados contextos normativos, torna possível, mediante sua aplicação, a igualdade material. Vale destacar também a interrelação do princípio do Estado social com o princípio de autonomia. A este respeito, cabe considerar que a estruturação autonômica do Estado é um princípio metodológico ineludível para a análise constitucional em muitos âmbitos e, entre estes, o do Estado social não é menos importante. Em todo caso, a diversidade de desenvolvimentos constitucionais do Estado social se corresponde também com uma heterogeneidade de elementos conformadores deste princípio. Destes elementos conformadores, o que mais genuinamente se corresponde com seu significado constitucional é o de igualdade substancial.

8. No que se refere ao tratamento jurisprudencial do Estado social, poder-se-ia afirmar que o Tribunal Constitucional utiliza uma metodologia que está estreitamente relacionada com as exigências derivadas da Constituição do pluralismo. O Tribunal não estabelece um conceito prévio da fórmula constitucional do Estado social e democrático de direito, como uma imagem fixa, para ser utilizada no juízo constitucional. Cabe considerar, a este respeito, que a fórmula constitucional é o produto de uma sedimentação de elementos diversos, heterogêneos e potencialmente contraditórios. Daí que seja a interação de cada um destes elementos com a própria fórmula o que acabe por determinar seu sentido. Esta concreção não se pode realizar de maneira estática e isolada, senão de modo dinâmico e relacional, como ocorre com outros institutos constitucionais. Deste modo, mais que a um conteúdo pré-estabelecido, o princípio do Estado social e democrático de Direito apela a uma fórmula de 
contornos elásticos, que se concretam no momento em que se tem que resolver os problemas jurídico-constitucionais. Na jurisprudência constitucional sobre o Estado social merecem destaque dois aspectos: o relativo à reversibilidade das prestações sociais e o relativo à consecução da igualdade substancial. Em ambas as questões se manifesta de maneira global o Estado social na sua ativação ou realização e na sua eventual desativação. A jurisprudência constitucional dá uma margem de decisão ampla ao legislador democrático, admitindo a possibilidade de reduzir prestações sociais, porém estabelecendo limites materiais (núcleo indisponível) e formais (necessidade de fundamentação). Em relação à promoção da igualdade, a interação entre o artigo 9.2 e o $14 \mathrm{CE}$ (que nem sempre é confllitiva, senão que pode ser também uma relação de convergência) baseia-se no estabelecimento de limitações à ação legislativa (embora seja para completá-la quando se produzem omissões parciais). Só numa medida muito reduzida, o artigo 9.2 pode gerar direitos a uma atuação dos poderes públicos.

\section{BIBLIOGRAFIA}

ABELLAN, A.M., <<La problemática del Estado de bienestar como fenómeno internacional $>>$, em M.A. GARCIA HERRERA (dir.): El constitucionalismo en la crisis del Estado social, Universidad del País Vasco, Bilbao, 1997.

ABENDROTH, W., <<Der demokratische und soziale Rechtsstaat als politischer Auftrag >>, 1965, versão espanhola, $<<$ El Estado del derecho democrático y social como proyecto político $>>$ em W. ABENDROTH, E. FORSTHOFF, K. DOEHRING, El Estado social, CEC, Madrid, 1986.

APARICIO, M.A., <<El Estado social en la jurisprudencia del Tribunal Constitucional $>>$ em G. CAMARA VILLAR, J. CANO BUESO, Estudios sobre el Estado social, Tecnos, Madrid, 1993.

ARNOLD, R., <<Bases dogmáticas del principio del Estado social en el derecho constitucional alemán>>, em G. CAMARA VILLAR, J. CANO BUESO, Estudios sobre el Estado social, Tecnos, Madrid, 1993.

BALAgueR, F., Fuentes del Derecho, Vol. II: Ordenamiento general del Estado y ordenamientos autonómicos, Tecnos, Madrid, 1992.

BALAGUER, F., <<Constitución normativa y ciencia del Derecho>>, em AAVV: Estudios de Derecho Público en Homenaje a Juan José Ruiz-Rico, Editorial Tecnos, Vol. I, Madrid, 1997.

BALAGUER, F., <<Das System der Rechtsquellen in der spanischen Verfassungsrechtsordnung >>, Jahrbuch des öffentlichen Rechts der Gegenwart, Mohr Siebeck, Tübingen, Tübingen, Bd. 49, 2001-I, pp. 413-442.

BALAGUER, F., <<Capacidad creativa y límites del legislador en relación con los derechos fundamentales. La garantía del contenido esencial de los derechos>>, em Miguel Ángel Aparicio Pérez (Coord.) Derechos Constitucionales y pluralidad de ordenamientos. CEDECS, Barcelona, 2001-II, pp. 93-116.

BARCELONA, P., <<Los sujetos y las normas. El concepto de Estado social $>>$, em E. OLIVAS, Problemas de legitimación en el Estado social, Editorial Trotta, Madrid, 1991.

BENDA, E., <<El Estado social de Derecho>>, 1994, en BENDA, MAIHOFER, VOGEL, HESSE, HEYDE, Manual de Derecho constitucional, IVAP, MARCIAL PONS, Madrid, 1996.

CANTARO, A., <<El declive de la constitución económica del Estado social $>>$, em M.A. GARCIA HERRERA (dir.): El constitucionalismo en la crisis del Estado social, Universidad del País Vasco, Bilbao, 1997. 
CARMONA CUENCA, E., El Estado social de Derecho en la Constitución, Consejo Económico y Social, Madrid, 2000.

CARMONA CUENCA, E., <<Las normas constitucionales de contenido social: delimitación y problemática de su eficacia jurídica>>, em Revista de Estudios Políticos, nº 76, Madrid, 1992.

CAPELLA, J.R., <<La crisis del Estado del bienestar en la crisis de la civilización>>, em E. OLIVAS, Problemas de legitimación en el Estado social, Editorial Trotta, Madrid, 1991.

COSSIO DIAZ, J.R., Estado social y derechos de prestación, CEC, Madrid, 1989.

CRUZ VILLALON, P., <<Los derechos sociales y el Estatuto de Andalucía >>, em G. CAMARA VILLAR, J. CANO BUESO, Estudios sobre el Estado social, Tecnos, Madrid, 1993. DE CABO, C., La crisis del Estado social, PPU, Barcelona, 1986.

DE CABO, C., <<La crisis del Estado social $>>$, em G. CAMARA VILLAR, J. CANO BUESO, Estudios sobre el Estado social, Tecnos, Madrid, 1993.

DE VEGA GARCIA, P., <<En torno al concepto político de Constitución>>, em M.A. GARCIA HERRERA (dir.): El constitucionalismo en la crisis del Estado social, Universidad del País Vasco, Bilbao, 1997.

DE VEGA GARCIA, P., <<Mundialización y derecho constitucional: la crisis del principio democrático en el constitucionalismo actual $>>$, Revista de Estudios Políticos, $n^{\circ} 100$, Madrid, 1998.

DIAZ, E., Estado de Derecho y sociedad democrática, 1966, Madrid, Taurus, 1986.

DOEHRING, K., <<Sozialstaat, Rechtsstaat und freiheitlich-demokratische Grundordnung >>, 1978, versão espanhola, <<Estado social, Estado de derecho y orden democrático $>>$, em W. ABENDROTH, E. FORSTHOFF, K. DOEHRING, El Estado social, CEC, Madrid, 1986.

DOGLIANI, M. $<<$ Los problemas del constitucionalismo en la crisis del Estado social $>>$, em M.A. GARCIA HERRERA (dir.): El constitucionalismo en la crisis del Estado social, Universidad del País Vasco, Bilbao, 1997.

FORSTHOFF, E., <<Verfassungsprobleme des Sozialstaats $>>$, 1961, versão espanhola, $<<$ Problemas constitucionales del Estado social $>>$, em W. ABENDROTH, E. FORSTHOFF, K. DOEHRING, El Estado social, CEC, Madrid, 1986.

FORSTHOFF, E., <<Begriff und Wesen des sozialen Rechtsstaates $>>$, 1975, versão espanhola, $<<$ Concepto y esencia del Estado social de Derecho $>>$, em W. ABENDROTH, E. FORSTHOFF, K. DOEHRING, El Estado social, CEC, Madrid, 1986.

GALLEGO-DIAZ, S./DE LA CUADRA, B., Crónica secreta de la Constitución, Tecnos, Madrid, 1989.

GARCIA COTARELO, R., Del Estado del bienestar al Estado del malestar, CEC, Madrid, 1986.

GARCIA COTARELO, J., Voz <<Estado social>>, em J.J. GONZALEZ ENCINAR (ed.), Diccionario del sistema político español, Akal editor, Madrid, 1984.

GARCIA HERRERA, M.A., MAESTRO BUELGA, G., <<Regulación constitucional y posibilidad del Estado social >>, RVAP, $\mathrm{n}^{\circ} 22,1988$.

GARCIA HERRERA, M.A., MAESTRO BUELGA, G., Marginalidad, Estado social y prestaciones autonómicas, CEDECS, Barcelona, 1999.

GARCIA PELAYO, M., <<El Estado social y sus implicaciones $>>$, 1975, constante da recopilação do mesmo autor Las transformaciones del Estado contemporáneo, Alianza Editorial, $4^{a}$ ed., Madrid, 1984.

DiREITOS FundamentaIS E J JUSTIÇA N 4 - JUL./SET. 2008 
GARCIA PELAYO, M., <<El Estado social y democrático de Derecho en la Constitución Española>>, constante da recopilação do mesmo autor Las transformaciones del Estado contemporáneo, Alianza Editorial, $4^{\mathrm{a}}$ ed., Madrid, 1984.

GARRORENA MORALES, A., El Estado español como Estado social y democrático de Derecho, Tecnos, Madrid, 1984.

GOMES CANOTILHO, J.J., <<Metodología fuzzy y camaleones normativos en la problemática actual de los derechos económicos, sociales y culturales $>>$, em Derechos y Libertades, Revista del Instituto Bartolomé de las Casas. Año III, nº 6, Madrid, 1998.

HÄBERLE, P., <<Grundrechte im Leistungsstaat>>, 1971, na recopilação do mesmo autor, Die Verfassung des Pluralismus, Athenäum, Königstein/Ts., 1980.

HÄBERLE, P., <<Gemeineuropäisches Verfassungsrecht>>, EuGRZ, 30. August 1991. Versão espanhola: <<Derecho constitucional común europeo>>, REP, na 79, Enero-Marzo 1993.

HÄBERLE, P., <<Incursus. Perspectiva de una doctrina constitucional del mercado: siete tesis de trabajo $>>$, Pensamiento Constitucional, Año IV, nº 4, Lima, 1997. Igualmente, $<<$ Siete tesis para una teoría constitucional del mercado>>, Revista de Derecho Constitucional Europeo, n. 5, enero-junio de 2006. http://www.ugr.es/ redce/

HÄBERLE, P., $<<$ Los derechos fundamentales en el espejo de la jurisprudencia del Tribunal Constitucional Federal Alemán. Exposición y crítica >> na Revista de la Facultad de Derecho de la Universidad de Granada, n² 2, Granada, 1999.

HELLER, H., <<Rechtsstaat oder Diktatur?>>, 1929, versão espanhola $<<$ ¿Estado de Derecho o Dictadura? >>, 1929, na recopilação do mesmo autor $<<$ Escritos políticos $>>$, Alianza Editorial, Madrid, 1985.

JIMENEZ CAMPO, J., Voz <<Estado social y democrático de Derecho $>>$, en J.J. GONZALEZ ENCINAR (ed.), Diccionario del sistema político español, Akal editor, Madrid, 1984.

LASSALLE, F., Über Verfassungswesen, 1862, versão espanhola, ¿Qué es una Constitución?, Ariel, Barcelona, 1984.

LOPEZ y LOPEZ, A.M., <<Estado social y sujeto privado: una reflexión finisecular >>, QUADERNI FIORENTINI, 25, 1996.

LUCAS MURILLO, P., <<Normas programáticas, Estatutos y autonomía comunitaria >>, Revista de Derecho Político, n. 21, Madrid, 1984.

LUCAS MURILLO, P., <<El Estatuto como programa y el control y la participación en la política económica y social como exigencias del Estado social $>>$, em G. CAMARA VILLAR, J. CANO BUESO, Estudios sobre el Estado social, Tecnos, Madrid, 1993.

LUCAS VERDU, P., La lucha por el Estado de Derecho, Studia Albornotiana, Bolonia, 1975.

LUCAS VERDU, P., Comentario al artículo $1^{\circ} \mathrm{CE}$, en O. Alzaga (dir.) Comentarios a las Leyes Políticas, EDERSA, Madrid, 1983.

MONTILLA MARTOS, J.A., $<<$ El mandato constitucional de promoción de la igualdad real y efectiva en la jurisprudencia constitucional y su integración con el principio de igualdad $>>$, em AAVV, Estudios de Derecho Püblico. Homenaje a Juan José Ruiz-Rico, Tecnos, Madrid, 1997.

PEREZ AYALA, A., <<Los orígenes del constitucionalismo social. Una aproximación desde una perspectiva histórico-comparativa >>, em M.A. GARCIA HERRERA (dir.): El constitucionalismo en la crisis del Estado social, Universidad del País Vasco, Bilbao, 1997. 
PEREZ LUÑO, A.E., <<La evolución del Estado social y la transformación de los derechos fundamentales>>, em E. OLIVAS, Problemas de legitimación en el Estado social, Editorial Trotta, Madrid, 1991.

PEREZ ROYO, J., Voz <<Estado Social de Derecho>>, em AAVV, Enciclopedia Jurídica Básica, vol. II, Civitas, Madrid, 1995.

PEREZ VILLALOBOS, M. C., C., Estado social y Comunidades Autónomas, Madrid, Tecnos, 2002.

PRIETO SANCHIS, L., <<Los Derechos sociales y el principio de igualdad sustancial $>>$, Revista del Centro de Estudios Constitucionales, n² 22, Madrid, 1995.

POSADA, A., La crísis del Estado y el Derecho Político, C. Bermejo Impresor, Madrid, 1934.

SERRA, F., <<El futuro del Estado social $>>$, em E. OLIVAS, Problemas de legitimación en el Estado social, Editorial Trotta, Madrid, 1991. 